\title{
Denitrification and total nitrate uptake in streams of a tropical landscape
}

\author{
J. D. Potter,,${ }^{1,3}$ W. H. McDowell,${ }^{1}$ J. L. Merriam, ${ }^{1}$ B. J. Peterson,${ }^{2}$ and S. M. Thomas ${ }^{2}$ \\ ${ }^{1}$ Department of Natural Resources and the Environment, University of New Hampshire, Durham, New Hampshire 03824 USA \\ ${ }^{2}$ Ecosystems Center, Marine Biological Laboratory, Woods Hole, Massachusetts 02543 USA
}

\begin{abstract}
Rapid increases in nitrogen $(\mathrm{N})$ loading are occurring in many tropical watersheds, but the fate of $\mathrm{N}$ in tropical streams is not well documented. Rates of nitrate uptake and denitrification were measured in nine tropical low-order streams with contrasting land use as part of the Lotic Intersite Nitrogen eXperiment II (LINX II) in Puerto Rico using short term (24-hour) additions of $\mathrm{K}^{15} \mathrm{NO}_{3}$ and $\mathrm{NaBr}$. Background nitrate concentrations ranged from 105 to $997 \mu \mathrm{g} \mathrm{N} / \mathrm{L}$, and stream nitrate uptake lengths were long, varying from 315 to $8480 \mathrm{~m}$ (median of $1200 \mathrm{~m}$ ). Other indices of nitrate uptake (mass transfer coefficient, $V_{\mathrm{f}}$ $[\mathrm{cm} / \mathrm{s}]$, and whole-stream nitrate uptake rate, $U\left[\mu \mathrm{g} \mathrm{N} \cdot \mathrm{m}^{-2} \cdot \mathrm{s}^{-1}\right]$ ) were low in comparison to other regions and were related to chemical, biological, and physical parameters. Denitrification rates were highly variable $\left(0-133 \mu \mathrm{g} \mathrm{N} \cdot \mathrm{m}^{-2} \cdot \mathrm{min}^{-1}\right.$; median $=15 \mu \mathrm{g}$ $\mathrm{N} \cdot \mathrm{m}^{-2} \cdot \min ^{-1}$ ), were dominated by the end product $\mathrm{N}_{2}\left(\right.$ rather than $\mathrm{N}_{2} \mathrm{O}$ ), and were best predicted by whole-stream respiration rates and stream $\mathrm{NO}_{3}$ concentration. Denitrification accounted for $1-97 \%$ of nitrate uptake with five of nine streams having $35 \%$ or more of nitrate uptake via denitrification, showing that denitrification is a substantial sink for nitrate in tropical streams. Whole-stream nitrate uptake and denitrification in our study streams closely followed first-order uptake kinetics, indicating that $\mathrm{NO}_{3}$ uptake is limited by delivery of substrate $\left(\mathrm{NO}_{3}\right)$ to the organisms involved in uptake or denitrification. In the context of whole-catchment nitrogen budgets, our finding that in-stream denitrification results in lower proportional production of $\mathrm{N}_{2} \mathrm{O}$ than terrestrial denitrification suggests that small streams can be viewed as the preferred site of denitrification in a watershed in order to minimize greenhouse gas $\mathrm{N}_{2} \mathrm{O}$ emissions. Conservation of small streams is thus critical in tropical ecosystem management.
\end{abstract}

Key words: denitrification; $\mathrm{N}$ loading; $\mathrm{N}_{2} \mathrm{O}$ emissions; nitrate uptake; Puerto Rico; tropical streams; tropics.

\section{INTRODUCTION}

Until recently, most anthropogenic $\mathrm{N}$ inputs occurred in the industrialized, temperate regions of the world. This situation is rapidly changing with economic expansion in the tropics, where nearly two-thirds of Earth's anthropogenic energy-related $\mathrm{N}$ inputs will take place by 2020 (Galloway et al. 1994). Current rates of nitrogen export in tropical watersheds with minimal disturbance are about five-fold greater than in temperate regions with similar runoff (Downing et al. 1999). This export often has a high percentage of dissolved organic nitrogen (DON; $\sim 35 \%$ ), while dissolved inorganic $\mathrm{N}$ also makes up about $35 \%$ of that $\mathrm{N}$ export and particulate $\mathrm{N}$ making up the rest (McDowell and Asbury 1994, Lewis et al. 1999). Human activities induce a shift from organic to inorganic forms of exported $\mathrm{N}$, with mobile nitrate $\left(\mathrm{NO}_{3}\right)$ dominating outputs (Cole et al. 1993). Nitrate loading is known to

Manuscript received 13 July 2009; revised 29 January 2010; accepted 1 February 2010. Corresponding Editor: K. N. Eshleman.

${ }^{3}$ E-mail: jody.potter@unh.edu reduce biotic efficiency of $\mathrm{N}$ uptake in streams (O'Brien et al. 2007, Mulholland et al. 2008) and to cause coastal eutrophication from stream and river inputs (Turner and Rabalais 1994, Vitousek et al. 1997). Understanding the fate of $\mathrm{NO}_{3}$ in stream and river systems is thus critical in efforts to maintain ecological health in aquatic ecosystems. This is especially true in a rapidly urbanizing region such as Puerto Rico, where $\mathrm{N}$ export in highly urbanized basins is higher than the most impacted zones in Northern Europe (Ortiz-Zayas et al. 2006).

Studies of in-stream $\mathrm{N}$ dynamics are largely lacking in the tropics and in urban tropical streams in particular, with most of the published work focused on reference and agricultural streams in Costa Rica, Puerto Rico, and Amazonian Brazil. The few studies that have been published suggest that the high inorganic $\mathrm{N}$ concentrations typically found in tropical streams result in little or no limitation to primary production (Pringle et al. 1986, Neill et al. 2006) with no studies to date indicating the functional response of tropical streams in response to anthropogenic N loading (Earl et al. 2006, O'Brien et al. 2007). In temperate streams biotic (Hall and Tank 2003, Webster et al. 2003, Mulholland et al. 2006) and 
hydrologic controls (Valett et al. 1996, Wollheim et al. 2001) on inorganic $\mathrm{N}$ have been documented, but they have not been examined in detail in the tropics. Understanding controls on nitrate uptake and denitrification is a critical research need for Puerto Rico, where short transit times from land to the ocean, as well as high population densities, make estuaries and the coastal zone particularly sensitive to nitrogen-induced eutrophication (Ortiz-Zayas et al. 2006).

To protect coastal water quality, the most desirable fate of bioavailable $\mathrm{N}$ in streams is denitrification, the microbial reduction of $\mathrm{NO}_{3}$ to unavailable gaseous $\mathrm{N}$ $\left(\mathrm{N}_{2}\right.$ and $\left.\mathrm{N}_{2} \mathrm{O}\right)$. In temperate streams denitrification can be a significant sink of total $\mathrm{N}$ inputs (20-35\%) with higher rates occurring in systems that receive substantial anthropogenic N (Seitzinger 1988). Denitrification in the near-stream zone of streams in Puerto Rico has been found to be important in regulating nitrogen flux (Bowden et al. 1992, McDowell et al. 1992, 1996, Chestnut and McDowell 2000), but in-stream denitrification has been largely ignored. Differentiating between production of $\mathrm{N}_{2} \mathrm{O}$ and $\mathrm{N}_{2}$ during denitrification is also critical because of the potent greenhouse effects of $\mathrm{N}_{2} \mathrm{O}$ (Wang et al. 1976). The ratio of $\mathrm{N}_{2} \mathrm{O}: \mathrm{N}_{2}$ is related to oxygen, $\mathrm{H}_{2} \mathrm{~S}$, and $\mathrm{NO}_{3}$ availability and is lower in aquatic systems than soils (Firestone et al. 1980, Seitzinger and Kroeze 1998). $\mathrm{N}_{2} \mathrm{O}$ emissions from rivers are thought to be a significant global source of $\mathrm{N}_{2} \mathrm{O}$ (Seitzinger and Kroeze 1998), and there is a critical need to quantify stream $\mathrm{N}_{2} \mathrm{O}$ production and emission (and their controls) in the tropics (Seitzinger et al. 2000).

We hypothesize that the high ambient nitrate concentrations, warm water temperatures, and large organic matter inputs associated with high rates of terrestrial primary production would make denitrification particularly important as a sink for $\mathrm{NO}_{3}{ }^{-}$in tropical streams even though overall $\mathrm{NO}_{3}$ uptake is low. We test this hypothesis using ${ }^{15} \mathrm{~N}$ tracers that allow quantification of whole stream denitrification rates without the physical and chemical perturbations of the acetylene block method (Mulholland et al. 2004). We performed these experiments in small tropical streams of Puerto Rico in various types of land use with a range of chemical, biological, and physical characteristics that allows us to analyze the relationships between these characteristics and rates of various $\mathrm{N}$ cycling processes. The specific questions we ask include: (1) What is the relative importance of assimilatory $\mathrm{NO}_{3}$ uptake and denitrification in tropical streams with widely varying land use? (2) Are tropical streams different than their temperate counterparts in terms of the rates and controls on $\mathrm{NO}_{3}$ uptake and denitrification? (3) What factors regulate $\mathrm{NO}_{3}$ uptake and denitrification? (4) What are the functional responses of these streams to the increased $\mathrm{NO}_{3}$ concentrations caused by human activities in their watersheds? (5) What proportion of stream denitrification results in $\mathrm{N}_{2} \mathrm{O}$ as the gaseous end product, and does this differ from denitrification in tropical soils?

\section{Methods \\ Site description}

This study was conducted in and around the Luquillo Experimental Forest (LEF), on the Caribbean island of Puerto Rico. The area is characterized by steep slopes in forested areas at higher altitudes and moderate to steep slopes in the lower, more human-impacted regions. The elevation of our study watersheds ranged from 10 to 675 $\mathrm{m}$. Annual rainfall ranges from $150 \mathrm{~cm}$ in metropolitan San Juan to $250 \mathrm{~cm}$ in the lower altitudes of the forest and increases with elevation (McDowell et al., in press). The mean annual temperature ranges from $19^{\circ} \mathrm{C}$ to $26^{\circ} \mathrm{C}$. Total agricultural land in Puerto Rico has decreased significantly in the last 50 years, while forested and urban lands have increased due to socioeconomic factors (Grau et al. 2003). Much of the agricultural land is divided into small parcels and is interspersed with forest fragments, while urban land is developed intensively. Nine streams (first to third order) were selected in the study area in three different classes of land use: reference (tropical rainforest), agriculture, and urban. Land-use categories were assigned based on visual observation of the dominant land use adjacent to the study reach.

The reference streams were located in the Luquillo Mountains of northeastern Puerto Rico. The three streams, Quebrada Bisley, Rio Icacos Tributary (RIT), and Quebrada Pared, are steep, confined and very shaded (Tables 1 and 2). Percent forested land was not below $99.7 \%$ in any of the three watersheds. They have steeper channel slopes than the other streams in this study.

The agricultural streams were located at lower elevations in the coastal plains. Quebrada Grande is a sandy-bottomed stream draining horse and cattle pasture. It has an incised stream channel that is heavily disturbed by frequent rain events. Quebrada Maizales is mostly cobble and boulder, draining banana plantation and horse pasture as well as suburban housing developments. Portions of its stream bank have been stabilized with concrete to maintain the stream course. Quebrada Vaca flows through cattle pasture and patchy forest. The streambed consists mostly of gravel and the riparian zone is mostly broadleaf trees. Grande and Maizales have very few trees in their riparian zones.

The three urban streams Quebrada Petunia, Rio Mameyes Tributary (MTrib), and Quebrada Ceiba are mostly gravel-bottomed. Petunia and MTrib have thick, tree-lined riparian cover, while Ceiba has a more open canopy. Petunia drains a residential area in metropolitan San Juan and contained the highest $\mathrm{NO}_{3}$ concentrations of any of the study sites. MTrib and Ceiba also drain residential areas in the towns of Palmer and Ceiba, respectively. Evidence of periodic sewage leaks directly into the streams was observed in all three of our urban streams. 
TABLE 1. Characteristics of streams used in the study.

\begin{tabular}{|c|c|c|c|c|c|c|c|c|c|c|c|c|c|c|}
\hline \multirow[b]{2}{*}{$\begin{array}{l}\text { Stream } \\
\text { name }\end{array}$} & \multirow{2}{*}{$\begin{array}{l}\text { Water- } \\
\text { shed } \\
\text { area (ha) }\end{array}$} & \multicolumn{3}{|c|}{$\begin{array}{c}\text { Watershed cover } \\
\text { type }(\%)\end{array}$} & \multirow[b]{2}{*}{$\begin{array}{l}\text { Sub. } \\
\text { type }\end{array}$} & \multirow{2}{*}{$\begin{array}{l}\text { Reach } \\
\text { length } \\
(\mathrm{m})\end{array}$} & \multirow[b]{2}{*}{$\begin{array}{l}\text { Slope } \\
(\%)\end{array}$} & \multirow[b]{2}{*}{$\underset{(\mathrm{L} / \mathrm{s})}{Q}$} & \multirow[b]{2}{*}{$\begin{array}{l}\text { Width } \\
(\mathrm{m})\end{array}$} & \multirow[b]{2}{*}{$\begin{array}{l}\text { Depth } \\
(\mathrm{m})\end{array}$} & \multicolumn{3}{|c|}{$\begin{array}{c}\text { Hydraulic } \\
\text { characteristics }\end{array}$} & \multirow[b]{2}{*}{$\begin{array}{l}\text { Velocity } \\
(\mathrm{cm} / \mathrm{s})\end{array}$} \\
\hline & & Native & $\begin{array}{l}\text { Agri- } \\
\text { culture }\end{array}$ & Urban & & & & & & & $A_{\mathrm{S}} / A$ & $\alpha\left(\mathrm{s}^{-1}\right)$ & $\begin{array}{c}F_{\text {med }}^{200} \\
\text { (fraction) }\end{array}$ & \\
\hline Bisley & 58 & 99.7 & 0 & 0.3 & $\mathrm{Bl} / \mathrm{Be}$ & 385 & 12.9 & 12.5 & 3.20 & 0.07 & 0.380 & 0.00013 & 0.078 & 5.366 \\
\hline RIT & 30 & 100 & 0 & 0 & $\mathrm{~S} / \mathrm{Fg}$ & 365 & 3.1 & 20.0 & 1.18 & 0.27 & 0.131 & 0.00005 & 0.242 & 6.159 \\
\hline Pared & 64 & 99.8 & 0.2 & 0 & $\mathrm{G} / \mathrm{C}$ & 525 & 14.2 & 5.2 & 2.74 & 0.04 & 0.236 & 0.00002 & 0.030 & 1.852 \\
\hline Grande & 95 & 28.3 & 69.3 & 2.4 & $\mathrm{~S} / \mathrm{Fg}$ & 690 & 1.4 & 12.3 & 1.02 & 0.06 & 0.318 & 0.01875 & 0.010 & 20.000 \\
\hline Maizales & 265 & 61.7 & 34.3 & 4 & $\mathrm{G}^{\circ}$ & 450 & 2.5 & 25.0 & 3.53 & 0.35 & 0.000 & 0.00576 & 0.000 & 2.011 \\
\hline Vaca & 172 & 60.5 & 32.2 & 7.4 & G & 490 & 2.5 & 80.7 & 1.96 & 0.16 & 0.164 & 0.00004 & 0.031 & 6.073 \\
\hline Petunia & 110 & 6.7 & 0 & 92.3 & $\mathrm{G}$ & 350 & 4.0 & 4.7 & 1.80 & 0.11 & 0.128 & 0.00004 & 0.038 & 2.315 \\
\hline MTrib & 160 & 42 & 1.5 & 56.7 & $\mathrm{G}$ & 375 & 2.4 & 23.2 & 2.46 & 0.41 & 0.151 & 0.00005 & 0.021 & 2.278 \\
\hline Ceiba & 505 & 44.2 & 2.7 & 53.2 & G & 625 & 1.6 & 49.5 & 2.73 & 0.07 & 0.045 & 0.00005 & 0.006 & 6.755 \\
\hline
\end{tabular}

Notes: Dominant stream substrate (sub.) types are: Bl, boulder; Be, bedrock; S, sand; Fg, fine gravel; G, gravel; and C, cobble. Other variables are $Q$, discharge and transient storage parameters $\left(A_{\mathrm{S}} / A, \alpha, F_{\mathrm{med}}\right) . A_{\mathrm{S}} / A$ is the size of the transient storage zone adjusted to stream area. Transient storage is the area of the stream where flow paths are moving much more slowly than the average velocity of the stream channel (Bencala 1983). All the hydraulic characteristics were determined by using the OTIS-P model (Runkel 1998) from the $\mathrm{NaCl}$ injections. The dispersion coefficient $\alpha$ is a measure of the lateral movement of solutes in a stream channel, which is primarily controlled by turbulence. $F_{\text {med }}^{200}$ is a measure of the fraction of median water travel time due to storage within the stream reach (Runkel 2002). Abbreviated stream names are: RIT, Rio Icacos Tributary; and MTrib, Rio Mameyes Tributary.

\section{Experimental procedures}

Tracer enrichment experiments with ${ }^{15} \mathrm{NO}_{3}$ experiments were conducted in the nine streams as part of the Lotic Intersite Nitrogen eXperiment II (LINX II; Mulholland et al. 2008). Experiments were conducted in February and March over three years (2004-2006). The ${ }^{15} \mathrm{~N}$ addition experiments, sampling, and analysis followed the methods of Hall et al. (2009) and Mulholland et al. (2009) and will not be explained in detail here.

Uptake lengths ( $S_{\mathrm{w}}$; in the water compartment) were calculated using regressions of the natural $\log$ of the ${ }^{15} \mathrm{~N}$ flux value (corrected for background and dilution) against distance below the ${ }^{15} \mathrm{~N}$ injection. The slope of this regression is the distance-normalized $\mathrm{NO}_{3}$ uptake rate and the inverse of the slope is the $\mathrm{NO}_{3}$ uptake length $\left(S_{\mathrm{w}}\right)$. Whole stream nitrate uptake rate $(U ; \mu \mathrm{g}$ $\mathrm{N} \cdot \mathrm{m}^{-2} \cdot \mathrm{s}^{-1}$ ) was calculated by the following equation:

$$
U=F /\left(S_{\mathrm{w}} \times w\right)
$$

where $w$ is the average wetted width and $F$ is the nutrient flux. The mass transfer coefficient $\left(V_{\mathrm{f}}\right)$ was calculated by dividing $U$ by the stream water $\mathrm{NO}_{3}$ concentration (Newbold et al. 1981, Stream Solute Workshop 1990). Assimilatory ${ }^{15} \mathrm{~N}$ uptake by biomass was calculated from the mass of ${ }^{15} \mathrm{~N}$ tracer found in each biomass compartment.

Denitrification rates (production of $\mathrm{N}_{2}$ and $\mathrm{N}_{2} \mathrm{O}$ ) were determined from the production of ${ }^{15} \mathrm{~N}_{2}$ and ${ }^{15} \mathrm{~N}_{2} \mathrm{O}$ in the study reach using the approach described in Mulholland et al. (2004). First, tracer ${ }^{15} \mathrm{~N}_{2}$ and ${ }^{15} \mathrm{~N}_{2} \mathrm{O}$ MF values were computed and ${ }^{15} \mathrm{~N}_{2}$ and ${ }^{15} \mathrm{~N}_{2} \mathrm{O}$ flux were calculated with the MF values and the $\mathrm{N}_{2}$ and $\mathrm{N}_{2} \mathrm{O}$ mass values (statistically corrected for incomplete headspace mixing and air contamination). We solved for the ${ }^{15} \mathrm{~N}_{2}$ and ${ }^{15} \mathrm{~N}_{2} \mathrm{O}$ production rates by fitting the following relationship to the longitudinal pattern in tracer ${ }^{15} \mathrm{~N}_{2}$ and ${ }^{15} \mathrm{~N}_{2} \mathrm{O}$ flux $(A)$ with distance $x$ (in units of meters) downstream from the ${ }^{15} \mathrm{~N}$ addition point:

$$
A=\left(\frac{k_{\text {den }} \times N_{0}}{k_{2}-k_{1}}\right) \times\left(e^{-k 1 x}-e^{-k 2 x}\right)
$$

\begin{tabular}{|c|c|c|c|c|c|c|c|c|c|c|}
\hline $\begin{array}{l}\text { Stream } \\
\text { name }\end{array}$ & $\begin{array}{l}\text { Experiment date } \\
\text { (Feb-Mar) }\end{array}$ & $\begin{array}{c}\mathrm{NO}_{3} \\
(\mu \mathrm{g} \mathrm{N} / \mathrm{L})\end{array}$ & $\begin{array}{c}\mathrm{NH}_{4} \\
(\mu \mathrm{g} \mathrm{N} / \mathrm{L})\end{array}$ & $\begin{array}{c}\text { DON } \\
(\mu \mathrm{g} \mathrm{N} / \mathrm{L})\end{array}$ & $\begin{array}{c}\text { SRP } \\
(\mu \mathrm{g} \mathrm{P} / \mathrm{L})\end{array}$ & $\begin{array}{l}\text { Water } \\
\text { temper- } \\
\text { ature } \\
\left({ }^{\circ} \mathrm{C}\right)\end{array}$ & $\begin{array}{c}\text { PAR } \\
\text { (mol } \\
\text { quanta. } \\
\mathrm{m}^{-2} \cdot \mathrm{d}^{-1} \text { ) }\end{array}$ & $\begin{array}{c}\text { Daily } \\
\text { GPP } \\
\left(\mathrm{g} \mathrm{O}_{2} \cdot\right. \\
\left.\mathrm{m}^{-2} \cdot \mathrm{d}^{-1}\right)\end{array}$ & $\begin{array}{c}\text { Daily ER } \\
\left(\mathrm{g} \mathrm{O}_{2}\right. \\
\left.\mathrm{m}^{-2} \cdot \mathrm{d}^{-1}\right)\end{array}$ & $\begin{array}{c}\mathrm{GPP} / \\
\mathrm{ER}\end{array}$ \\
\hline Bisley & 2004 & 171 & 3 & 10 & 22 & 21 & 0.15 & 0.01 & 2.42 & 0.00 \\
\hline RIT & 2005 & 131 & 7 & 23 & 0 & 19 & 0.50 & 0.47 & 4.49 & 0.10 \\
\hline Pared & 2006 & 105 & 3 & 280 & 7 & 22 & 1.55 & 0.39 & 0.42 & 0.92 \\
\hline Grande & 2004 & 276 & 11 & 70 & 13 & 23 & 6.39 & 5.18 & 7.64 & 0.68 \\
\hline Maizales & 2005 & 206 & 7 & 78 & 12 & 23 & 13.95 & 7.29 & 5.31 & 1.37 \\
\hline Vaca & 2006 & 440 & 3 & 167 & 9 & 23 & 1.52 & 3.08 & 15.69 & 0.20 \\
\hline Petunia & 2004 & 997 & 15 & 53 & 26 & 24 & 0.02 & 0.34 & 4.60 & 0.07 \\
\hline MTrib & 2005 & 174 & 2204 & 847 & 310 & 21 & 0.82 & 7.13 & 7.41 & 0.96 \\
\hline Ceiba & 2006 & 512 & 50 & 11 & 22 & 25 & 1.98 & 9.33 & 11.74 & 0.79 \\
\hline
\end{tabular}

TABLE 2. Stream chemical and biological characteristics during each of the ${ }^{15} \mathrm{~N}$ addition experiments.

Note: Abbreviations are: DON, dissolved organic nitrogen; SRP, soluble reactive phosphorus; PAR, photosynthetically available radiation; GPP, gross primary productivity; ER, ecosystem respiration. 
where $k_{\mathrm{den}}$ is the denitrification rate; $N_{0}$ is the flux of ${ }^{15} \mathrm{~N}$-nitrate calculated at the point of the injection; $k_{1}$ is the measured rate of decline in streamwater ${ }^{15} \mathrm{~N}$-nitrate flux with distance due to all processes (in units of $\mathrm{m}^{-1}$ ); and $k_{2}$ is the $\mathrm{N}_{2}$ or $\mathrm{N}_{2} \mathrm{O}$ gas exchange rate through the air-water interface per unit distance (units of $\mathrm{m}^{-1}$ ). Values of $k_{2}$ were determined from a propane or $\mathrm{SF}_{6}$ injection experiment. A least-squares fitting procedure (Solver Tool, Microsoft Excel 2003; Microsoft, Redmond, Washington, USA) was used to determine the values of $k_{\text {den }}$ from fitting the model to $A$. Denitrification rate $k_{\text {den }}$ was then multiplied by stream $\mathrm{NO}_{3}$ flux and divided by average stream width to give the areal denitrification rate. $\mathrm{N}_{2} \mathrm{O}$ emission rates were estimated from dissolved $\mathrm{N}_{2} \mathrm{O}$ concentrations in stream water and the $\mathrm{N}_{2} \mathrm{O}$ gradient between stream water and atmosphere.

Physical, chemical, and biological variables were measured within three days of the ${ }^{15} \mathrm{~N}$ experiment. Average stream width, velocity, and discharge were measured each day of the experiment. Water travel time and transient storage zone size and exchange rates were determined once during the experiment from a $\mathrm{NaCl}$ injection. The conductivity data were entered in the OTIS-P model, which was used to quantify the hydrologic parameters affecting solute transport (Runkel 1998). Whole stream gross primary productivity (GPP) and ecosystem respiration (ER) were measured concurrently with the ${ }^{15} \mathrm{~N}$ addition experiment using the two-station dissolved oxygen (DO) method with data logging sondes (YSI 6920; YSI, Yellow Springs, Ohio, USA). Air-water gas exchange was measured by addition of a conservative gas (propane or sulfur hexafluoride) either during or immediately after the experiment. Gas exchange rate was calculated in terms of the fractional decline in conservative gas (corrected for dilution due to groundwater input between stations) between two measurement stations. Stream water chemistry $\left(\mathrm{Br}, \mathrm{Cl}, \mathrm{NO}_{3}, \mathrm{NH}_{4}, \mathrm{SRP}\right.$, and DOC) was also collected at all stations before, during, and after the experiment. For more detailed descriptions for these experimental methods see Hall et al. (2009) and Mulholland et al. (2009).

\section{Statistical analysis}

Simple linear regression using ordinary least squares was performed on relationships between measured hydrological, biological, and chemical variables and $\mathrm{N}$ uptake parameters that were the primary relationships found across North American streams (Hall et al. 2009, Mulholland et al. 2009). The explanatory variables used to assess controls on total $\mathrm{NO}_{3}$ removal (described by $S_{\mathrm{W}}, V_{\mathrm{f}}$, and $U$ ) were specific discharge (discharge divided by stream wetted width; $Q / w$ ), $\mathrm{NO}_{3}$ concentration, and GPP (Hall et al. 2009). The explanatory variables used to assess controls on denitrification (described by $S_{\mathrm{W} \text { den }}, V_{\mathrm{f} \text { den }}$, and $U_{\mathrm{den}}$ ) were $Q / w, \mathrm{NO}_{3}$ concentration, ER, and $F_{\text {med }}^{200}$ (a transient water storage metric, standardized to a stream length of $200 \mathrm{~m}$; Mulholland et al. 2009). Relationships were considered significant where $P<0.05$. All total $\mathrm{N}$ removal and denitrification parameters were $\log _{10}$-transformed prior to statistical analysis to improve normality, except fractional parameters that were arcsine-square-root transformed. Diel differences in $\mathrm{NO}_{3}$ cycling metrics were examined using paired $t$ tests, but subsequent simple linear regression analyses were performed on the average of the day/night measures for each stream. Statistical analyses were performed with SPSS 17 (SPSS Inc., Chicago, Illinois, USA).

The statistical models examining the functional response of stream biota to increasing nutrient concentration were done with the following statistical tests. The relationship between $U$ (and $U_{\text {den }}$ ) and $\mathrm{NO}_{3}$ was considered to follow first-order response if there was a significant regression found with $\log$ transformed independent and dependent variables and if the slope was equal to 1 , which was determined by a $t$ test of the slope of the regression. The relationship was considered to follow the efficiency loss model (O'Brien et al. 2007) if this same regression had a slope between 0 and 1 . The relationship would be considered saturated if there was a significant fit with the Michaelis-Menten model on nontransformed data and calculated $K_{\mathrm{S}}$ was within the range of $\mathrm{NO}_{3}$ concentrations in our study. Saturation was also tested using $S_{\mathrm{W}}$ by linear regression between $S_{\mathrm{W}}$ and $\mathrm{NO}_{3}$ concentration. In this case MichaelisMenten would be valid if there was a linear relationship, first-order kinetics would be valid if there was no relationship, and the efficiency loss model would be valid if there was a power relationship with the slope significantly less than 1. A full explanation of these models can be found in O'Brien et al. (2007).

\section{RESUlts \\ Physical and chemical parameters}

Stream discharge $(Q)$ ranged from $4.7 \mathrm{~L} / \mathrm{s}$ (Petunia) to $80.7 \mathrm{~L} / \mathrm{s}$ (Vaca) during the ${ }^{15} \mathrm{~N}$ additions (Table 1; median $=20.3 \mathrm{~L} / \mathrm{s}$ ) and discharge was relatively constant throughout the experiments in each stream. The nine streams ranged in mean width from $1 \mathrm{~m}$ (Grande) to 3.5 $\mathrm{m}$ (Maizales) and in mean depth from $4 \mathrm{~cm}$ (Pared) to 35 $\mathrm{cm}$ (Vaca). Velocity was unrelated to discharge and was highest in a sandy bottom stream (Grande, $20 \mathrm{~cm} / \mathrm{s}$ ). PAR (Table 2) ranged from 0.02 (Petunia) to $13.95 \mathrm{~mol}$ quanta $\cdot \mathrm{m}^{-2} \cdot \mathrm{d}^{-1}$ (Maizales) and was related to canopy cover.

Dispersion coefficients $(D)$ ranged from 0.024 (Maizales) to $0.455 \mathrm{~m}^{2} / \mathrm{s}$ (Grande) and were highly dependent on water velocity $\left(r^{2}=0.61, P=0.01\right)$. The area of the transient storage zone $\left(A_{\mathrm{S}}\right)$ varied between 0 (Maizales) and $0.13 \mathrm{~m}^{2}$ (Vaca), while the size of the transient storage zone normalized for stream size $\left(A_{\mathrm{S}} / A\right.$; Table 1) ranged from 0 (Maizales) to 0.38 (Bisley). Storage zone exchange coefficient $(\alpha)$ ranged from 0.00002 (Pared) to $0.01875 \mathrm{~s}^{-1}$ (Grande), but most were 
below $0.001 \mathrm{~s}^{-1}$, and $F_{\text {med }}^{200}$ (Table 1) ranged from 0 (Maizales) to 0.24 (RIT).

$\mathrm{NO}_{3}$ concentrations varied from $105 \mu \mathrm{g} \mathrm{N} / \mathrm{L}$ in Pared to $997 \mu \mathrm{g} \mathrm{N} / \mathrm{L}$ in Petunia (Table 2) and were an indication of the severity of anthropogenic impacts on the streams. Concentrations of $\mathrm{NH}_{4}$ had a median of 7 $\mu \mathrm{g} \mathrm{N} / \mathrm{L}$, with the highest concentrations in Ceiba (50 $\mu \mathrm{g}$ $\mathrm{N} / \mathrm{L})$ and MTrib (2204 $\mu \mathrm{g} \mathrm{N} / \mathrm{L})$. $\mathrm{NO}_{3}$ was the largest proportion of dissolved $\mathrm{N}$, with the exceptions of Pared, where DON was the dominant dissolved form of $\mathrm{N}$, and MTrib, where $\mathrm{NH}_{4}$ dominated. Concentrations of $\mathrm{NH}_{4}$ during the ${ }^{15} \mathrm{~N}$ experiment in MTrib were about seven to eight times higher than when measured prior to the experiment due to a temporary input of raw sewage entering directly into the stream. This was not realized until after the experiment had begun.

\section{Metabolism and biomass}

Fine benthic organic matter (FBOM) was the dominant organic matter compartment (mean $=57 \%$ of total ash-free dry mass [AFDM]) in all streams except RIT, where coarse benthic organic matter (CBOM) was dominant (44\% of total AFDM) and Grande where epilithon was $35 \%$ of total AFDM. Ceiba had the highest total standing stock of organic matter (140 g AFDM $/ \mathrm{m}^{2}$ ) and the mean was $82 \mathrm{~g} \mathrm{AFDM} / \mathrm{m}^{2}$ across all streams.

Stream water temperature ranged from $19.0^{\circ}$ to $25.3^{\circ} \mathrm{C}$ (Table 2). Light varied almost three orders of magnitude, from $0.02 \mathrm{~mol}$ quanta $\cdot \mathrm{m}^{-2} \cdot \mathrm{d}^{-1}$ in an urbanized stream with very thick riparian cover (Petunia) to $13.95 \mathrm{~mol}$ quanta $\cdot \mathrm{m}^{-2} \cdot \mathrm{d}^{-1}$ in an agricultural stream with no riparian vegetation (Maizales). All streams were net heterotrophic except Maizales, which had a $\mathrm{P} / \mathrm{R}$ above 1. GPP varied three orders of magnitude, ranging from $0.01 \mathrm{~g} \mathrm{O}_{2} \cdot \mathrm{m}^{-2} \cdot \mathrm{d}^{-1}$ (Bisley) to $9.33 \mathrm{~g} \mathrm{O}_{2} \cdot \mathrm{m}^{-2} \cdot \mathrm{d}^{-1}$ (Ceiba). GPP was positively correlated with PAR (log scale, $\left.r^{2}=0.46, P=0.046\right)$ and watershed area $\left(r^{2}=0.67, P=0.01\right)$. Ecosystem respiration (ER) was highly variable among streams, ranging from 0.42 (Pared) to $15.7 \mathrm{~g} \mathrm{O}_{2} \cdot \mathrm{m}^{-2} \cdot \mathrm{d}^{-1}$ (Vaca). ER was negatively correlated with stream gradient $\left(r^{2}=\right.$ $0.47, P=0.04)$ and positively correlated with depth $\left(r^{2}=\right.$ $0.62, P=0.01)$ and discharge $\left(r^{2}=0.79, P=0.01\right)$.

\section{Nitrogen dynamics}

The uptake kinetics of $\mathrm{NO}_{3}$ varied considerably among streams and there was no statistically significant pattern in the day to night differences in any of the $\mathrm{NO}_{3}$ uptake parameters. Three streams had poor model fits for one of their sampling periods (RIT night, MTrib day, and Vaca night), so only one sampling period was used in the following summary and regression relationships. The uptake length $\left(S_{\mathrm{W}}\right.$, Fig. 1) for $\mathrm{NO}_{3}$ was shortest in Pared (mean $=315 \mathrm{~m})$, while $S_{\mathrm{W}}$ was longest in Vaca (day $=8480 \mathrm{~m}$ ). $S_{\mathrm{W}}$ had a significant positive relationship with $Q / w\left(r^{2}=0.72 ; P=0.00\right)$. The average uptake velocity $\left(V_{\mathrm{f}}\right)$, ranged from $0.13 \mathrm{~mm} / \mathrm{min}$
(Petunia; Fig. 1) to $0.94 \mathrm{~mm} / \mathrm{min}$ (Maizales). $V_{\mathrm{f}}$ was not related to $\mathrm{NO}_{3}$ concentration (Fig. 2b) but it had a significant positive relationship with GPP (Fig. 3c; $r^{2}=$ $0.44, P=0.05)$. Areal uptake rate ( $U$, Fig. 1$)$ varied over an order of magnitude from a mean of $27 \mu \mathrm{g} \mathrm{N}$. $\mathrm{m}^{-2} \cdot \mathrm{min}^{-1}$ at RIT to $251 \mu \mathrm{g} \mathrm{N} \cdot \mathrm{m}^{-2} \cdot \mathrm{min}^{-1}$ at Ceiba. $U$ had a significant positive relationship with $\mathrm{NO}_{3}$ concentration (Fig. $2 \mathrm{a} ; r^{2}=0.47, P=0.04$ ) and GPP (Fig. 3a; $\left.r^{2}=0.80, P<0.01\right)$.

Total autotrophic assimilation of $\mathrm{NO}_{3}$ (mean $=15.62$ $\mathrm{mg} \mathrm{N} \cdot \mathrm{m}^{-2} \cdot \mathrm{d}^{-1}$ ) was generally higher than assimilation by heterotrophs associated with detrital pools (FBOM and CBOM; mean $\left.=12.7 \mathrm{mg} \mathrm{N} \cdot \mathrm{m}^{-2} \cdot \mathrm{d}^{-1}\right)$. The two biomass compartments with the most rapid $\mathrm{NO}_{3}$ uptake (per gram organic matter or AFDM) were roots attached to riparian vegetation (Pared, RIT, and Vaca) and CBOM as leaves (Ceiba, Petunia, Grande, and MTrib), with CBOM as wood (Bisley) and filamentous algae (Maizales) highest in the other two streams. This was despite the fact that FBOM was the dominant organic matter compartment across streams. Assimilation by roots might not be due to autotrophic uptake at our sites, since we observed significant biofilm on the roots at every stream where we did not attempt to separate the biofilm from the bulk roots.

A linear regression model of $U$ and $\mathrm{NO}_{3}$ (log transformed data) produced a statistically significant relationship with a slope not significantly different from 1 , indicating that uptake more closely followed firstorder kinetics than Michaelis-Menten saturation or the efficiency loss model. There was also no significant relationship between $S_{\mathrm{W}}$ and $\mathrm{NO}_{3}$ concentration, which also indicates that total $\mathrm{NO}_{3}$ uptake more closely follows first-order kinetics.

\section{Denitrification}

Areal denitrification rates $\left(U_{\text {den }}\right)$ ranged from a stream day/night average of $0 \mu \mathrm{g} \mathrm{N} \cdot \mathrm{m}^{-2} \cdot \mathrm{min}^{-1}$ (Pared) to $133 \mu \mathrm{g} \mathrm{N} \cdot \mathrm{m}^{-2} \cdot \mathrm{min}^{-1}$ (Vaca; Fig. 1) and as was the case with total $\mathrm{NO}_{3}$ uptake, denitrification varied unpredictably between night and day (only the night denitrification rates were used from Bisley due to poor model fit). ${ }^{15} \mathrm{~N}$ in $\mathrm{N}_{2}$ and $\mathrm{N}_{2} \mathrm{O}$ was detectable in all nine streams and $\mathrm{N}_{2}$ was the dominant end product of denitrification by two orders of magnitude compared to $\mathrm{N}_{2}$ O. $U_{\text {den }}$ had a significant positive relationship with $\mathrm{NO}_{3}$ concentration (Fig. $2 \mathrm{c} ; r^{2}=0.46 ; P=0.04$ ) and ER (Fig. 3d; $r^{2}=0.57 ; P=0.02$ ). Denitrification velocity $\left(V_{\mathrm{f} \text { den }}\right)$ and uptake length due to denitrification $\left(S_{\mathrm{W} \text { den }}\right)$ were not related to $\mathrm{NO}_{3}$ concentration (Fig. 2d) or any of the other parameters measured. First order kinetics better explains the relationship between denitrification rate $\left(U_{\text {den }}\right)$ and $\mathrm{NO}_{3}$ concentration across streams on log transformed data compared to Michaelis-Menten saturation or the efficiency loss model.

Denitrification accounted for $1-97 \%$ of nitrate uptake, with five of the nine streams having denitrification accounting for greater than $35 \%$ of total nitrate uptake. 

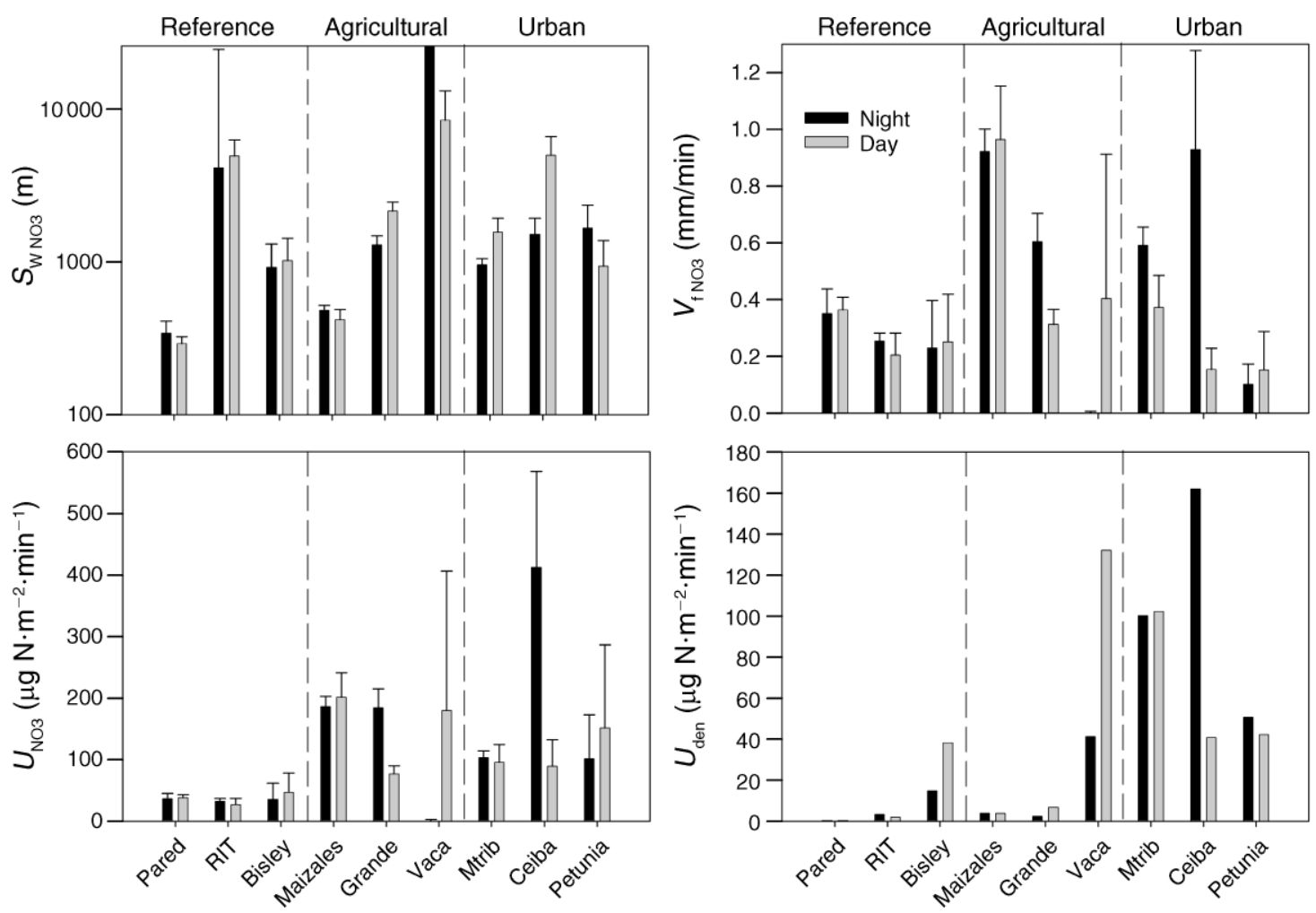

FIG. 1. $\mathrm{NO}_{3}$ uptake length $\left(S_{\mathrm{W}}\right)$, mass transfer velocity $\left(V_{\mathrm{f}}\right)$, areal uptake rate $\left(U_{\mathrm{NO} 3}\right)$, and denitrification rate $\left(U_{\mathrm{den}}\right)$ in the nine streams for both day and night sampling periods. Error bars are the upper $95 \%$ confidence interval from the linear regression of the decline in $\ln ^{15} \mathrm{NO}_{3}$ over distance downstream. (Uptake length for Vaca at night is infinite and therefore off scale.) Dotted lines separate streams of different land use.

This indicates that denitrification has the potential to be a substantial sink for nitrate. This average was slightly skewed by MTrib where sewage input increased $\mathrm{NH}_{4}$ concentrations from a background of $34 \mu \mathrm{g} \mathrm{N} / \mathrm{L}$ to 5658 $\mu \mathrm{g} \mathrm{N} / \mathrm{L}$ at the start of the reach. This ammonium was removed from solution quickly, through both assimilation and nitrification, and benthic $\mathrm{N}$ demand was mostly met by $\mathrm{NH}_{4} . \mathrm{NO}_{3}$ assimilation was only $2 \%$ of uptake, so the only uptake of $\mathrm{NO}_{3}$ was due to denitrification. Without MTrib, denitrification still averaged 25\% of $\mathrm{NO}_{3}$ uptake in the remaining eight streams.

Production of $\mathrm{N}_{2} \mathrm{O}$ ranged from 0 (Vaca) to $1.8 \mu \mathrm{g}$ $\mathrm{N} \cdot \mathrm{m}^{-2} \cdot \mathrm{h}^{-1}$ (Petunia) and was strongly related to $\mathrm{NO}_{3}$ concentration $\left(r^{2}=0.61, P=0.01\right)$. The ratio of $\mathrm{N}_{2} \mathrm{O}$ to $\mathrm{N}_{2}$ produced by denitrification was not correlated with $\mathrm{NO}_{3}$ concentration or any of the other variables, but was highest in the sandy-bottomed streams (RIT and Grande). $\mathrm{N}_{2} \mathrm{O}$ emission rates (from stream $\mathrm{N}_{2} \mathrm{O}$ concentration and air-water gas exchange) ranged from 8.5 (Pared) to $142.7 \mu \mathrm{g} \mathrm{N} \cdot \mathrm{m}^{-2} \cdot \mathrm{h}^{-1}$ (MTrib).

\section{Discussion}

\section{Total $\mathrm{NO}_{3}$ uptake in tropical streams}

Nitrate uptake rates are poorly constrained in tropical streams, and our data are some of the first to examine the variability in stream $\mathrm{NO}_{3}$ uptake across a broad range of land use and ambient $\mathrm{NO}_{3}$ concentrations. Uptake lengths $\left(S_{\mathrm{W}}\right)$ in our streams were relatively long, which was expected given the high $\mathrm{NO}_{3}$ concentrations we observed even in relatively pristine reference watersheds (105-171 $\mu \mathrm{g} \mathrm{N} / \mathrm{L})$. Among the few studies that have been published, our data fall within the range of previously reported values of $V_{\mathrm{f}}$ for tropical streams (Duff et al. 1996, Merriam et al. 2002, Neill et al. 2006). Our results show that values of $V_{\mathrm{f}}$ in tropical streams are similar to those in streams from other biomes with riparian forests that tend to reduce primary production (and presumably $\mathrm{N}$ uptake) by benthic algae, and have similar $\mathrm{NO}_{3}$ concentrations (e.g., streams from North Carolina, Massachusetts, Oregon, and Michigan, USA in LINX II; Mulholland et al. 2008 and Fig. 4). Nitrate uptake rates in our tropical streams are below those found in highly autotrophic, N-limited streams in other biomes such as the desert streams of Arizona (Grimm et al. 2005, Mulholland et al. 2008; Fig. 4).

Tropical stream $\mathrm{NO}_{3}$ uptake was correlated with a combination of physical, chemical, and biological factors (Figs. 2 and 3), similar to results obtained in most temperate zone streams (Hall and Tank 2003, Webster et al. 2003, Fellows et al. 2006, Mulholland et al. 2006, Hall et al. 2009). Biological nitrogen demand in Puerto Rican streams appears to be mostly autotrophic, 

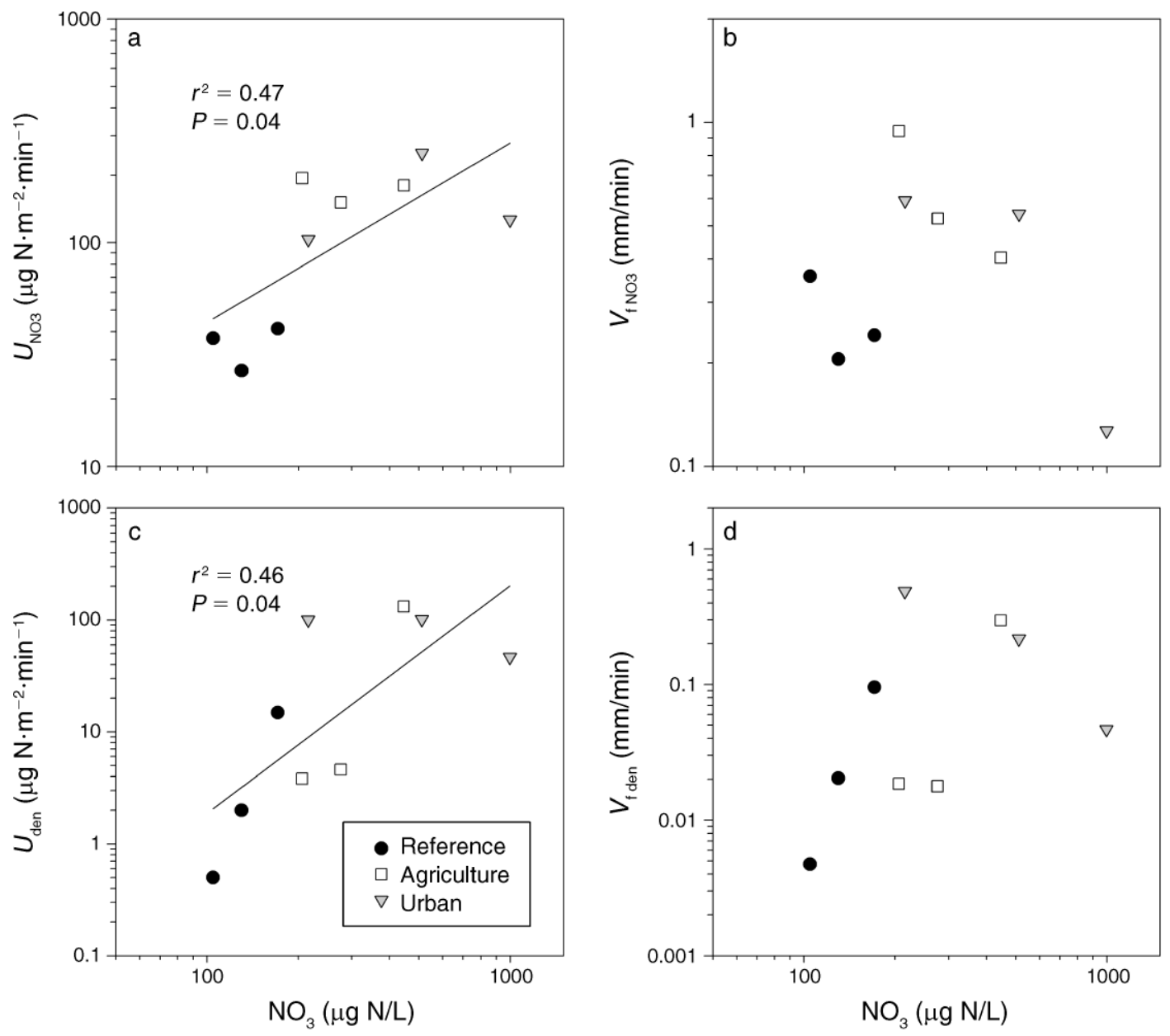

FIG. 2. (a) Total areal $\mathrm{NO}_{3}$ uptake $\left(U_{\mathrm{NO} 3}\right)$, (b) total $\mathrm{NO}_{3}$ uptake velocity $\left(V_{\mathrm{f} \mathrm{NO}}\right)$, (c) areal denitrification rate $\left(U_{\mathrm{den}}\right)$, and (d) denitrification velocity $\left(V_{\mathrm{f} \text { den }}\right)$ as a function of stream $\mathrm{NO}_{3}$ concentration in all nine study streams. Lines indicate significant relationships using simple log-linear regression.

based on the strong relationships we observed between nitrate uptake (as both $V_{\mathrm{f}}$ and $U$ ) and measures of GPP (Fig. 3). In streams in the Grand Teton National Park with comparable variation in both $V_{\mathrm{f}}$ and stream light levels, Hall and Tank (2003) also concluded that autotrophic production could account for most $\mathrm{NO}_{3}$ uptake. The importance of autotrophy in the regulation of diurnal variation in $\mathrm{NO}_{3}$ concentration has been shown in Walker Branch, Tennessee (Mulholland et al. 2006), but we did not see a discernable diurnal pattern in our streams. Despite the lack of evidence of diurnal patterns, the importance of autotrophic $\mathrm{N}$ demand is apparent in Puerto Rico in comparisons among streams.

Association of $\mathrm{N}$ demand with autotrophs suggests that light limitation is a major driver of biological $\mathrm{N}$ assimilation in streams across a variety of landscapes in Puerto Rico. In a comparison of stream metabolism in all the watersheds with forested riparian zones in LINX II, Bernot et al. (in press) found that GPP was the highest in Puerto Rico. They concluded that epilithon in Puerto Rican streams appears to have higher affinity for low light conditions, resulting in higher than predicted production and therefore greater potential for $\mathrm{N}$ assimilation than reference streams from other forested biomes. Energy limitation may also be an important driver of $\mathrm{N}$ dynamics in heavily forested streams in the Luquillo Experimental Forest (LEF) of Puerto Rico where there is little light reaching the stream and nitrification is the biggest major sink for added tracer $\mathrm{NH}_{4}$ (Merriam et al. 2002).

Physical controls on $\mathrm{NO}_{3}$ uptake were also evident in our results, as $S_{\mathrm{W}}$ was the shortest in streams that had low $Q / w$. Low $Q / w$ primarily enhances contact time of stream water with the stream bottom, thus enhancing benthic uptake. Comparison of two streams (Pared and Vaca) provides an example of the impacts of physical conditions on $S_{\mathrm{W}}$. In contrast to Pared, Vaca was especially deep relative to its flow (specific discharge was 30 times higher) and this translated into $\mathrm{NO}_{3} S_{\mathrm{W}}$ that was over 27 times longer. Nutrient $S_{\mathrm{W}}$ for streams in other biomes is also related to stream size (Peterson et al. 2001, Wollheim et al. 2001, Hall et al. 2009), 

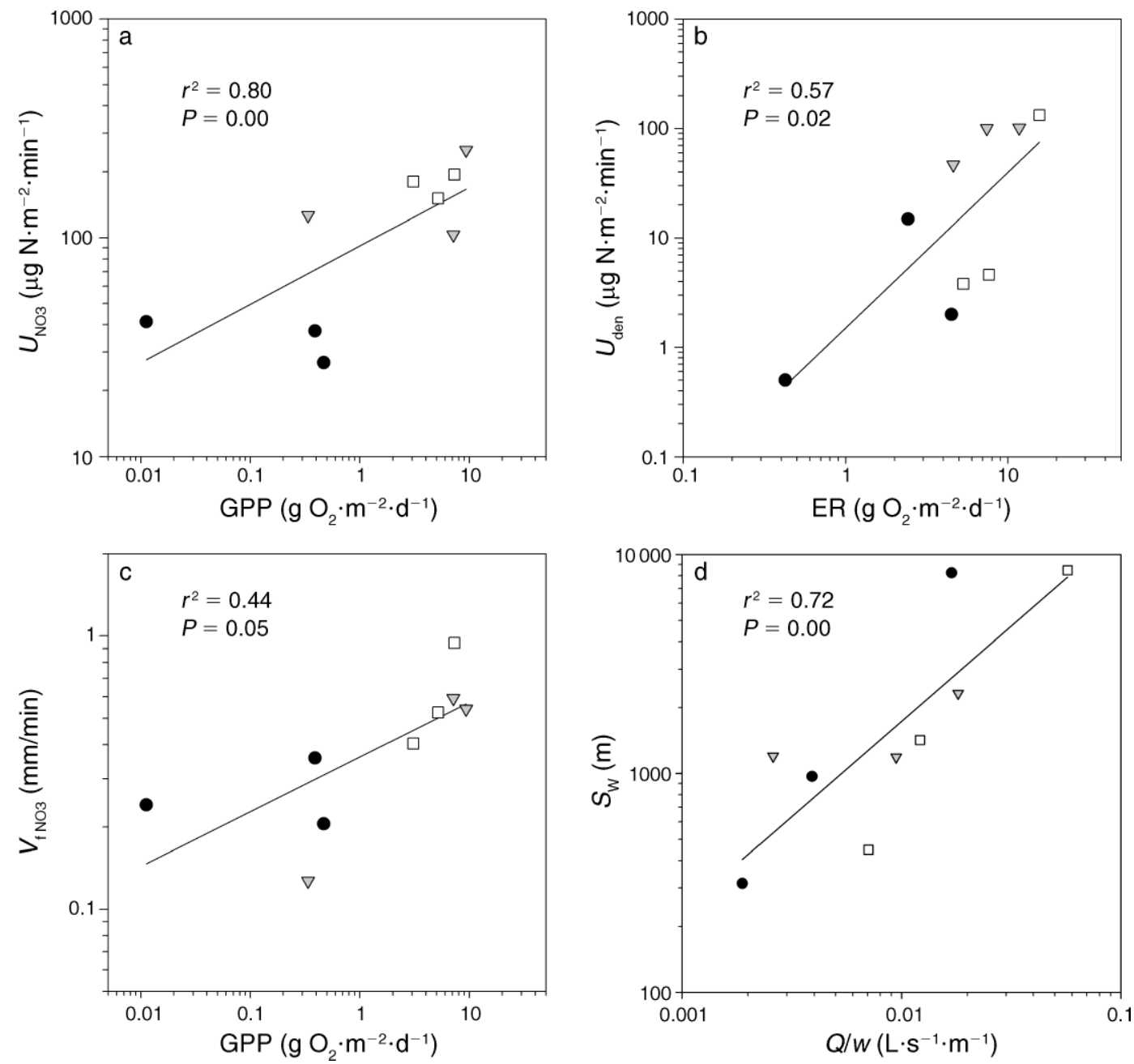

FIG. 3. (a) Total $\mathrm{NO}_{3}$ uptake rate $\left(U_{\mathrm{NO} 3}\right)$ as a function of gross primary production (GPP), (b) areal denitrification rate ( $\left.U_{\text {den }}\right)$ as a function of ecosystem respiration (ER), (c) total $\mathrm{NO}_{3}$ uptake velocity $\left(V_{\mathrm{f}}\right)$ as a function of GPP, and (d) total $\mathrm{NO}_{3}$ uptake length $\left(S_{\mathrm{W}}\right)$ as a function of specific discharge (discharge divided by stream wetted width $[Q / w]$ ) in all nine streams. All plots shown are significant relationships in simple log-linear regression.

indicating that the distance that a nutrient travels is strongly dependent on the stream's physical characteristics. The evidence provided here indicates that tropical streams behave in a similar manner, with stream $\mathrm{NO}_{3}$ uptake varying with physical characteristics of the stream channel.

Across a spatial gradient of streams receiving chronic $\mathrm{NO}_{3}$ inputs in Puerto Rico, first-order uptake kinetics better explained the biotic response to increasing $\mathrm{NO}_{3}$ concentration for total $\mathrm{NO}_{3}$ uptake (Fig. 2a) than did either Michaelis-Menten saturation or the efficiency loss model. This implies that uptake is limited by mass transport into the stream benthos rather than being limited by inherent limitations of the biota to assimilate or transform nitrate. A first-order response to increasing $\mathrm{NO}_{3}$ concentrations has been found in a single prairie reach in Kansas with short experimental fertilizations with $\mathrm{NO}_{3}$ (Dodds et al. 2002), but saturation or efficiency loss is the typical response across streams with chronic $\mathrm{NO}_{3}$ inputs (O'Brien et al. 2007, Mulholland et al. 2008). In a survey of 42 streams over three years in an urban watershed in Puerto Rico (Río Piedras), mean $\mathrm{NO}_{3}$ concentrations were $736 \mu \mathrm{g} \mathrm{N} / \mathrm{L}$ and several streams had concentrations between 1000 and $2500 \mu \mathrm{g} \mathrm{N} / \mathrm{L}$ (J. D. Potter et al., unpublished data). Similar studies in streams with this chronic level of N loading likely would help fill in the details about the occurrence of $\mathrm{N}$ saturation in tropical streams.

\section{Denitrification in tropical streams}

The data reported here provide some of the first empirical evidence that denitrification is a significant fraction of total $\mathrm{NO}_{3}$ uptake in tropical streams. Denitrification accounted for over $35 \%$ of total $\mathrm{NO}_{3}$ uptake in five of our nine streams, and averaged $33 \%$ across all nine streams. In their study on the importance 

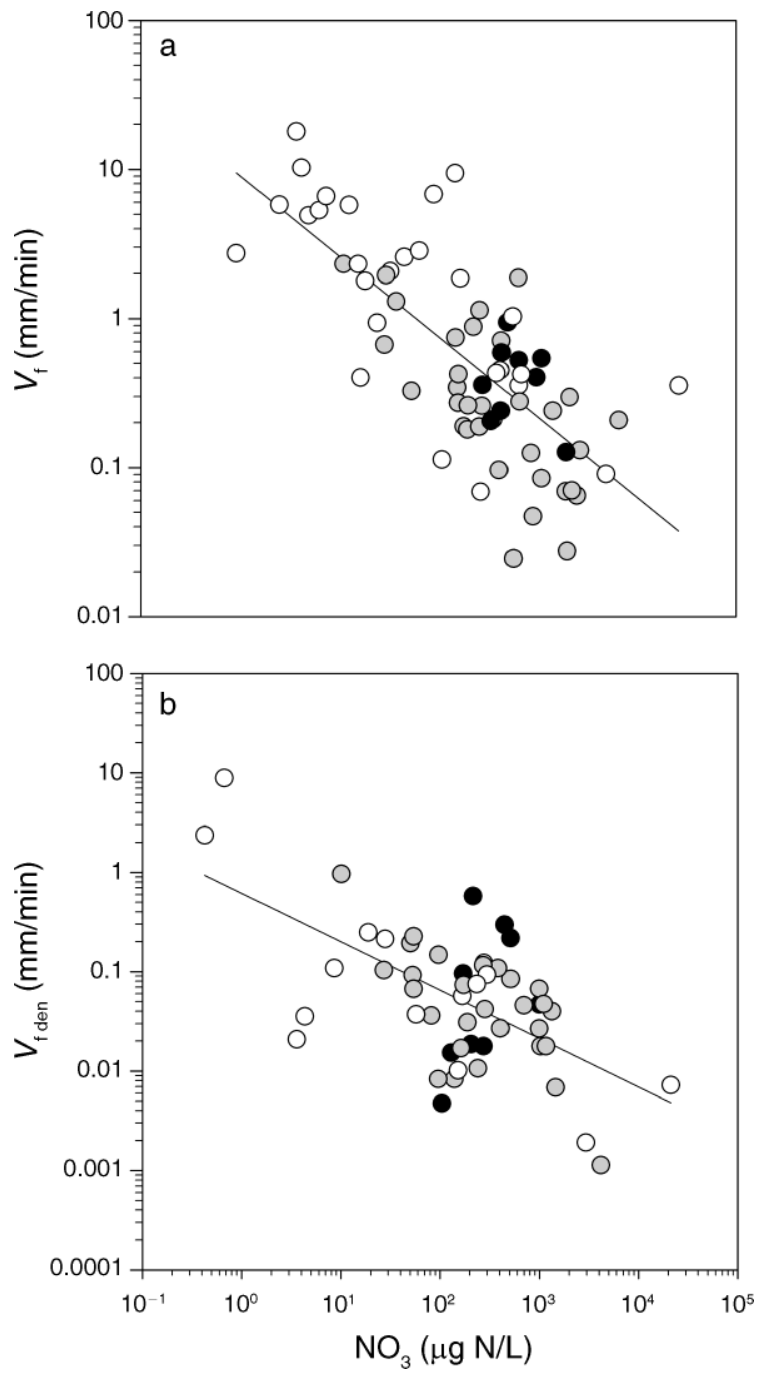

FIG. 4. Comparison of $\mathrm{NO}_{3}$ dynamics in our tropical sites and all watersheds studied in LINX II (Mulholland et al. 2008). (a) Total $\mathrm{NO}_{3}$ uptake velocity $\left(V_{\mathrm{f}}\right)$ and (b) $\mathrm{NO}_{3}$ uptake velocity due to denitrification $\left(V_{\mathrm{f} \text { den }}\right)$ as a function of average stream $\mathrm{NO}_{3}$ concentration. Black circles are from Puerto Rico, gray circles from other riparian forest based ecosystems, and open circles from ecosystems where riparian vegetation is not forest.

of $\mathrm{N}$ removal in headwater streams in the Mississippi River basin, Alexander et al. (2000) estimated a mean annual loss rate of $\mathrm{N}\left(k_{t}\right)$ via denitrification of $45.5 \%$ $\mathrm{d}^{-1}$. In headwater streams of Puerto Rico, the average $k_{t}$ was $67 \% \mathrm{~d}^{-1}$ across streams.

The nitrate uptake velocities resulting from denitrification $\left(V_{\mathrm{f} \text { den }}\right)$ in our Puerto Rican streams were highly variable, but within the range observed in other regions. There are several published studies that have used the reach-scale ${ }^{15} \mathrm{~N}$ tracer technique to quantify ambient rates of denitrification in biomes other than the tropics (Bohlke et al. 2004, Mulholland et al. 2004, 2008, 2009, O'Brien et al. 2007). Stream $V_{\mathrm{f} \text { den }}$ in Puerto Rico varies almost as much as does stream $V_{\mathrm{f} \text { den }}$ from all the other biomes, but this variation in denitrification $V_{\mathrm{f}}$ occurs over a smaller range in $\mathrm{NO}_{3}$ concentrations (Fig. 2d). Three of our streams (Ceiba, MTrib, and Vaca) have higher $V_{\mathrm{f}}$ den than streams with similar nitrate concentrations located in other regions (Fig. 4). This suggests that tropical streams have the potential for highly efficient denitrification efficiency, although this potential was only realized for a third of the streams studied.

Areal rates of tropical stream denitrification exhibited strong relationships with $\mathrm{NO}_{3}$ concentration (Fig. 2c) and whole stream ER (Fig. 3b). These relationships have also been found in several studies in temperate streams (Seitzinger et al. 2006, Mulholland et al. 2009), consistent with the physiological constraints on denitrification, with adequate supplies of $\mathrm{NO}_{3}$ and organic carbon, and zones of reduced oxygen concentrations. The correlation we observed between ER and $U_{\text {den }}$ indicates that energy availability may be a key driver of variation in denitrification rates among tropical streams. In areas of the stream with high organic matter, oxygen levels are likely reduced by aerobic respiration, and subsequently $\mathrm{NO}_{3}$ is used by anaerobic or facultative bacteria as an electron acceptor. Incoming groundwater may also provide a low-oxygen environment in many of our streams; groundwater entering Icacos tributaries averages $1.4 \mathrm{mg}$ oxygen/L (McDowell et al. 1992).

Areal rates of denitrification $\left(U_{\text {den }}\right)$ were higher in our study streams than those measured in other biomes at similar stream water $\mathrm{NO}_{3}$ concentrations, and had the highest average $U_{\text {den }}$ of all the LINX II streams, despite not having the highest $\mathrm{NO}_{3}$ concentrations. These results suggest that denitrification rates in small tropical streams are not primarily dependent upon $\mathrm{NO}_{3}$ supply, as they are across biomes (Mulholland et al. 2008), but rather are more closely related to stream respiration and the presence of anaerobic zones. The high rates of denitrification in tropical streams are likely due to denitrifying organisms evolving in an environment where climatic factors lead to high rates of $\mathrm{R}$ (year round warm water temperatures, large inputs of organic matter, high rainfall) and high ambient $\mathrm{NO}_{3}$. Although our study was conducted under conditions of base flow and our values represent rates at only one time of year, it illustrates the importance of denitrification in the removal of $\mathrm{N}$ in Puerto Rican streams. This is especially true when one considers that these denitrification rates are minimum estimates. They only include denitrification of water column $\mathrm{NO}_{3}$, and do not include the coupled nitrification-denitrification pathway, the denitrification of $\mathrm{NO}_{3}$ originally removed from the water column via assimilatory pathways (Seitzinger et al. 2006), or the denitrification associated with riparian $\mathrm{N}$ retention, which can be substantial (Chestnut and McDowell 2000).

\section{Tropical stream $\mathrm{NO}_{3}$ cycling and land use}

Several recent studies have shown that the effects of land use on stream $\mathrm{NO}_{3}$ cycling are primarily indirect, 
through impacts on $\mathrm{NO}_{3}$ concentrations and riparian cover and function (Hall et al. 2009, Mulholland et al. 2009). Our results indicate that tropical watersheds also follow these continental-scale patterns, since stream $\mathrm{NO}_{3}$ concentrations and GPP (correlated with percent canopy cover) were generally higher in urban and agricultural streams. Increased $\mathrm{NO}_{3}$ concentrations led to higher $U$ and $U_{\text {den }}$ (Fig. 2a, c) indicating a stimulation of overall $\mathrm{NO}_{3}$ uptake and denitrification, but we surprisingly found no significant relationship between $V_{\mathrm{f}}$ or $V_{\mathrm{f}}$ den and $\mathrm{NO}_{3}$ concentration among our nine study streams (Fig. 2b, d). We expected that as $\mathrm{NO}_{3}$ concentrations increased with anthropogenic impacts, there would be a reduction in the ability of these streams to retain $\mathrm{N}$, which has been seen in other regions (Bernot and Dodds 2005, O'Brien et al. 2007) and at the continental scale (Mulholland et al. 2008, Hall et al. 2009). The absence of this relationship may be due to the relatively limited number of sites in our study (e.g., relative to Mulholland et al. 2008), or the small range in $\mathrm{NO}_{3}$ concentrations, with even the reference streams having abundant $\mathrm{NO}_{3}$, or it may indicate a fundamental difference in the $\mathrm{NO}_{3}$ dynamics of tropical and temperate streams. This latter interpretation is made more plausible by the large differences in $\mathrm{N}$ cycling between tropical and temperate forests (e.g., Matson et al. 1999).

Changes in riparian cover and function associated with land use change appear to have different effects on overall $\mathrm{NO}_{3}$ uptake and denitrification. In the case of total $\mathrm{NO}_{3}$ uptake, the removal of riparian vegetation stimulates GPP (as indicated by correlation with PAR and percent canopy cover) and subsequently $V_{\mathrm{f}}$ (through assimilation). In the case of denitrification, the presence and function of the riparian zone is critical to stimulation of $\mathrm{NO}_{3}$ removal as indicated by its relationship with ER. In our tropical streams, ER increases with increasing stream depth, discharge, and FBOM standing stocks, but increases with decreasing stream gradient. This indicates that it is the presence of riparian zones that provide $\mathrm{OM}$ and the conditions that generate anaerobic zones that drives variation in rates of stream denitrification across the landscape. The majority of streams where these physical attributes are present in Puerto Rico are in watersheds with anthropogenic impacts (and elevated $\mathrm{NO}_{3}$ inputs), since forested areas are typically limited to the mountainous interior where stream velocities flush OM standing stocks and steep slopes limit the presence of riparian zones except in specific geologies (McDowell et al. 1992). Effectively, land use change occurs in places where denitrification can respond better to elevated inputs. If a goal of watershed management is ultimately to remove $\mathrm{NO}_{3}$ via denitrification, then management efforts to increase denitrification should take priority over an increase in assimilation, which may be only a temporary removal pathway. Management activities that focus on enhancing the riparian inputs of organic matter that help fuel stream respiration, and maintaining the channel geomorphology that facilitates the retention and decomposition of organic matter, should be a top priority for tropical ecosystem management.

\section{Stream denitrification and $\mathrm{N}_{2} \mathrm{O}$ degassing in a landscape context}

Concentrations of $\mathrm{N}_{2} \mathrm{O}$ in stream water reflect the combined effects of nitrification and denitrification occurring in ground water that is transported into the stream, as well as in the stream itself. Venting of $\mathrm{N}_{2} \mathrm{O}$ to the atmosphere by tropical streams appears to be a small component of total watershed $\mathrm{N}_{2} \mathrm{O}$ emissions. Watershed emissions of $\mathrm{N}_{2} \mathrm{O}$ are high in tropical sites (Matson and Vitousek 1990), yet $\mathrm{N}_{2} \mathrm{O}$ emissions from our streams $\left(0.85-14.27 \mathrm{ng} \mathrm{N} \cdot \mathrm{cm}^{-2} \cdot \mathrm{h}^{-1}\right)$ were similar to those found in temperate streams and rivers (Cole and Caraco 2001, Laursen and Seitzinger 2004). Areal $\mathrm{N}_{2} \mathrm{O}$ emission rates from our streams were similar to those of soils (Macy 2005) in two of the same watersheds used in this study $\left(6.53 \mathrm{ng} \mathrm{N} \cdot \mathrm{cm}^{-2} \cdot \mathrm{h}^{-1}\right.$ in Bisley stream compared to $3.24 \mathrm{ng} \mathrm{N} \cdot \mathrm{cm}^{-2} \cdot \mathrm{h}^{-1}$ in Bisley soils; 3.74 ng N$\cdot \mathrm{cm}^{-2} \cdot \mathrm{h}^{-1}$ in RIT compared to $8.31 \mathrm{ng} \mathrm{N} \cdot \mathrm{cm}^{-2} \cdot \mathrm{h}^{-1}$ in Icacos soils). Total $\mathrm{N}_{2} \mathrm{O}$ loss is thus mostly from soils at the watershed scale, because streams contribute only a small fraction $(0.6 \%)$ of watershed surface area. Emission of $\mathrm{N}_{2} \mathrm{O}$ from the stream surface amounts to only $0.1 \%$ of the total $\mathrm{N}_{2} \mathrm{O}$ emissions measured in the Icacos watershed, and $1.3 \%$ in Bisley. This estimate of $1.3 \%$ in the Bisley watershed is the same value that was found in the Hudson River basin (Cole and Caraco 2001). In agricultural (predominantly pasture) watersheds areal rates of $\mathrm{N}_{2} \mathrm{O}$ emission are about 10 -fold higher in the stream than in soils (Erickson et al. 2001), but still only average about $3 \%$ of overall $\mathrm{N}_{2} \mathrm{O}$ emissions in the watershed.

The efficiency with which streams convert denitrification end products to $\mathrm{N}_{2}$ results in a small role for stream emissions in watershed-scale $\mathrm{N}_{2} \mathrm{O}$ production, but masks the important role played by streams in watershed-scale estimates of denitrification. The ratio of $\mathrm{N}_{2} \mathrm{O}$ to $\mathrm{N}_{2}$ produced by soils in Puerto Rico as a result of denitrification is about 1:1 (Chestnut et al. 1999), which is much greater than the range found in our streams $(0.001-0.025)$ and streams from other studies (Seitzinger 1988, Seitzinger et al. 2000, Mulholland et al. 2004). The $\mathrm{N}_{2} \mathrm{O}: \mathrm{N}_{2}$ is higher in tropical soils than streams probably due to the lower oxygen availability in stream sediments (Seitzinger and Kroeze 1998) rather than $\mathrm{NO}_{3}$ availability, since $\mathrm{NO}_{3}$ is abundant in both systems (McDowell and Asbury 1994, Chestnut et al. 1999). The large difference in $\mathrm{N}_{2} \mathrm{O}: \mathrm{N}_{2}$ indicates that denitrification in tropical streams proceeds to the most reduced end product $\left(\mathrm{N}_{2}\right)$ much more often than it does in tropical soils. It also suggests that a disproportionately large amount of denitrification in tropical watersheds may be occurring in stream channels, rather than on the landscape, even though $\mathrm{N}_{2} \mathrm{O}$ fluxes in tropical 
watersheds are considerable. In the Bisley watershed, for example, total denitrification in streams $(29 \mathrm{~kg} \mathrm{~N} / \mathrm{yr})$ is about $15 \%$ of total soil denitrification (195 kg N/yr; Chestnut et al. 1999), even though water surface area accounts for less than $1 \%$ of the total land surface. If we apply the same rate of soil denitrification from the reference watershed to our urban watersheds $(n=3)$, then $40-56 \%$ of total watershed denitrification occurs in the stream channel in our urban study watersheds. This estimate is likely conservative, since these watersheds have extensive impervious surfaces and hydrologic routing often bypasses soil infiltration, thereby limiting rates of soil denitrification. Small streams thus appear to play a particularly significant role in the biogeochemical cycles of urbanizing watersheds in the changing Puerto Rican landscape.

The extraordinarily high ratio of $\mathrm{N}_{2}: \mathrm{N}_{2} \mathrm{O}$ in denitrification end products has additional important implications for understanding denitrification at watershed and landscape scales. From the standpoint of minimizing greenhouse gas emissions, denitrification that occurs in streams is much more desirable than that which occurs in soils, as it produces much less of the radiatively important end product $\left(\mathrm{N}_{2} \mathrm{O}\right)$ per mole of nitrate that is denitrified. Protecting stream ecosystem function thus should be given high priority in urban land management in the tropics, and practices such as ditching and piping streams should be avoided. Secondly, the extraordinarily high and variable ratio means that measurement of denitrification in tropical streams cannot be accomplished through measurement of $\mathrm{N}_{2} \mathrm{O}$ production alone under field conditions. Direct measurement of the $\mathrm{N}_{2}$ produced during denitrification is essential for accurate measurement of stream denitrification, which means that isotopic approaches to understanding $\mathrm{N}$ dynamics in streams are particularly important in tropical biomes.

\section{ACKNOWLEDGMENTS}

This research was part of the Lotic Intersite Nitrogen eXperiment II (LINX II) funded by the National Science Foundation (DEB-0111410). Additional support was provided by the National Science Foundation to the Institute of Terrestrial Ecology at the University of Puerto Rico and the International Institute of Tropical Forestry (DEB-0218039 and DEB-0620919) through the Luquillo Long Term Ecological Research (LUQ LTER) program. We thank Wil Wollheim for model development and helpful comments on earlier drafts of the manuscript. Jake Beaulieu and Steve Hamilton performed the $\mathrm{N}_{2} \mathrm{O}$ analysis. Field assistance was provided by Michelle Daley, Gretchen Gettel, Amy Burgin, and Daniel von Schiller. Alonso Ramirez, Jorge Ortiz-Zayas, Fred Scatena, and Joe Troester provided logistical assistance and invaluable local knowledge.

\section{Literature Cited}

Alexander, R. B., R. A. Smith, and G. E. Schwarz. 2000. Effect of stream channel size on the delivery of nitrogen to the Gulf of Mexico. Nature 403:758-761.

Bencala, K. E. 1983. Simulation of solute transport in a mountain pool-and-riffle stream with a kinetic mass transfer model for sorption. Water Resources Research 19:732-738.
Bernot, M. J., and W. K. Dodds. 2005. Nitrogen retention, removal, and saturation in lotic ecosystems. Ecosystems 8: $442-453$.

Bernot, M. J., et al. In press. Inter-regional comparison of landuse effects on whole-stream metabolism. Freshwater Biology.

Bohlke, J. K., J. W. Harvey, and M. A. Voytek. 2004. Reachscale isotope tracer experiment to quantify denitrification and related processes in a nitrate-rich stream, mid-continent United States. Limnology and Oceanography 49:821-838.

Bowden, W. B., W. H. McDowell, C. E. Asbury, and A. M. Finley. 1992. Riparian nitrogen dynamics in two geomorphologically distinct tropical rainforest watersheds: nitrous oxide fluxes. Biogeochemistry 18:77-99.

Chestnut, T. J., and W. H. McDowell. 2000. C and N dynamics in the riparian and hyporheic zones of a tropical stream, Luquillo Mountains, Puerto Rico. Journal of the North American Benthological Society 19:199-214.

Chestnut, T. J., D. J. Zarin, W. H. McDowell, and M. Keller. 1999. A nitrogen budget for late-successional hillslope tabonuco forest, Puerto Rico. Biogeochemistry 46:85-108.

Cole, J. J., and N. F. Caraco. 2001. Emissions of nitrous oxide $\left(\mathrm{N}_{2} \mathrm{O}\right)$ from a tidal, freshwater river, the Hudson River, New York. Environmental Science and Technology 35:991-996.

Cole, J. J., B. L. Peirls, N. F. Caraco, and M. L. Pace. 1993. Nitrogen loading of rivers as a human driven process. Pages 141-157 in M. J. McDonnell and S. T. A. Prickett, editors. Humans as components of ecosystems: the ecology of subtle human effects and populated areas. Springer-Verlag, New York, New York, USA.

Dodds, W. K., et al. 2002. N uptake as a function of concentration in streams. Journal of the North American Benthological Society 22:206-220.

Downing, J. A., et al. 1999. The impact of accelerating land-use change on the N-Cycle of tropical aquatic ecosystems: current conditions and projected changes. Biogeochemistry 46:104-148.

Duff, J. H., C. M. Pringle, and F. J. Triska. 1996. Nitrate reduction in sediments of lowland tropical streams draining swamp forest in Costa Rica: an ecosystem perspective. Biogeochemistry 33:179-196.

Earl, S. R., H. M. Valett, and J. R. Webster. 2006. Nitrogen saturation in stream ecosystems. Ecology 87:3140-3151.

Erickson, H., M. Keller, and E. A. Davidson. 2001. Nitrogen oxide fluxes and nitrogen cycling during postagricultural succession and forest fertilization in the humid tropics. Ecosystems 4:67-84.

Fellows, C. C., H. M. Valett, C. N. Dahm, P. J. Mulholland, and S. A. Thomas. 2006. Coupling nutrient uptake and energy flow in headwater streams. Ecosystems 9:788-804.

Firestone, M. K., R. B. Firestone, and J. M. Tiedje. 1980. Nitrous oxide from soil denitrification: factors controlling its biological production. Science 208:749-751.

Galloway, J. N., H. Levy II, and P. S. Kasibhatla. 1994. Year 2020: consequences of population growth and development on the deposition of oxidized nitrogen. Ambio 23:120-123.

Grau, H. R., T. M. Aide, J. K. Zimmerman, J. R. Thomlinson, E. Helmer, and X. Zou. 2003. The ecological consequences of socioeconomic and land-use changes in postagricultural Puerto Rico. BioScience 53:1159-1168.

Grimm, N. B., R. W. Sheibley, C. L. Crenshaw, C. N. Dahm, W. J. Roach, and L. H. Zeglin. 2005. N retention and transformation in urban streams. Journal of the North American Benthological Society 24:626-642.

Hall, R. O., and J. L. Tank. 2003. Ecosystem metabolism controls nitrogen uptake in streams in Grand Teton National Park, Wyoming. Limnology and Oceanography 48:11201128.

Hall, R. O., Jr., et al. 2009. Nitrate removal in stream ecosystems measured by ${ }^{15} \mathrm{~N}$ addition experiments: total uptake. Limnology and Oceanography 54:653-665. 
Laursen, A. E., and S. P. Seitzinger. 2004. Diurnal patterns of denitrification, oxygen consumption and nitrous oxide production in rivers measured at the whole-reach scale. Freshwater Biology 49:1448-1458.

Lewis, W. M., Jr., J. M. Melack, W. H. McDowell, M. McClain, and J. E. Richey. 1999. Nitrogen yields from undisturbed watersheds in the Americas. Biogeochemistry 46: $149-162$.

Macy, J. G. 2005. Initial effects of nitrogen additions in two rainforest ecosystems of the Luquillo Mountains, Puerto Rico. Thesis. University of New Hampshire, Durham, New Hampshire, USA.

Matson, P. A., W. H. McDowell, A. R. Townsend, and P. M. Vitousek. 1999. The globalization of $\mathrm{N}$ deposition: ecosystem consequences in tropical environments. Biogeochemistry 46: 67-83.

Matson, P. A., and P. M. Vitousek. 1990. Ecosystem approach for the development of a global nitrous oxide budget. BioScience 40:667-672.

McDowell, W. H., and C. E. Asbury. 1994. Export of carbon, nitrogen, and major ions form three tropical montane watersheds. Limnological Oceanography 39:111-125.

McDowell, W. H., W. B. Bowden, and C. E Asbury. 1992. Riparian nitrogen dynamics in two geomorphologically distinct tropical rainforest watersheds: subsurface solute patterns. Biogeochemistry 18:53-75.

McDowell, W. H., C. P. McSwiney, and W. B. Bowden. 1996. Effects of hurricane disturbance on groundwater chemistry and riparian function in a tropical rainforest. Biotropica 28: 577-584.

McDowell, W. H., et al. In press. Geographic and ecological setting of the Luquillo Mountains. In N. Brokaw, T. A. Crowl, A. E. Lugo, W. H. McDowell, R. B. Waide, and M. R. Willig, editors. Disturbance, response, and tropical forest dynamics: long-term perspectives and implications. Oxford University Press, New York, New York, USA.

Merriam, J. L., W. H. McDowell, J. L. Tank, W. M. Wollheim, C. L. Crenshaw, and S. L. Johnson. 2002. Characterizing nitrogen dynamics, retention, and transport in a tropical rainforest stream using an in situ ${ }^{15} \mathrm{~N}$ addition. Freshwater Biology 47:143-160.

Mulholland, P. J., et al. 2009. Nitrate removal in stream ecosystems measured by ${ }^{15} \mathrm{~N}$ addition experiments: denitrification. Limnology and Oceanography 54(3):666-680.

Mulholland, P. J., et al. 2008. Stream denitrification across biomes and its response to anthropogenic nitrate loading. Nature 452:202-205.

Mulholland, P. J., S. A. Thomas, H. M. Valett, J. R. Webster, and J. Beaulieu. 2006. Effects of light on $\mathrm{NO}_{3}{ }^{-}$uptake in small forested streams: diurnal and day-to-day variations. Journal of the North American Benthological Society 25: 583-595.

Mulholland, P. J., H. M. Valett, J. R. Webster, S. A. Thomas, L. W. Cooper, S. K. Hamilton, and B. J. Peterson. 2004. Stream denitrification and total nitrate uptake rates measured using a field ${ }^{15} \mathrm{~N}$ tracer addition approach. Limnology and Oceanography 49:809-820.

Neill, C., L. A. Deegan, S. M. Thomas, C. L. Haupert, A. V. Krusche, V. M. Ballester, and C. L. Victoria. 2006. Deforestation alters the hydraulic and biogeochemical characteristics of small lowland Amazonian streams. Hydrological Processes 20:2563-2580.

Newbold, J. D., J. W. Elwood, R. V. O'Neill, and W. Van Winkle. 1981. Measuring nutrient spiraling in streams.
Canadian Journal of Fisheries and Aquatic Sciences 38: 860-863.

O’Brien, J. M., W. K. Dodds, K. C. Wilson, J. N. Murdock, and J. Eichmiller. 2007. The saturation of $\mathrm{N}$ cycling in Central Plains streams: ${ }^{15} \mathrm{~N}$ experiments across a broad gradient of nitrate concentrations. Biogeochemistry 84:3149.

Ortiz-Zayas, J. R., E. Cuevas, O. L. Mayo-Bracero, L. Donoso, I. Trebs, D. Figueroa-Nieves, and W. H. McDowell. 2006. Urban influences on the nitrogen cycle in Puerto Rico. Biogeochemistry 79:109-133.

Peterson, B. J., et al. 2001. Control of nitrogen export from watersheds by headwater streams. Science 292:86-90.

Pringle, C. M., P. Paaby-Hansen, P. D. Vaux, and C. R. Goldman. 1986. In situ nutrient assays of periphyton growth in a lowland Costa Rican stream. Hydrobiologia 134:207213.

Runkel, R. L. 1998. One-dimensional transport with inflow and storage (OTIS): a solute transport model for streams and rivers. USGS Water-Resources Investigations Report 984018. U.S. Geological Survey, Reston, Virginia, USA.

Runkel, R. L. 2002. A new metric for determining the importance of transient storage. Journal of the North American Benthological Society 21:529-543.

Seitzinger, S. P. 1988. Denitrification in freshwater and coastal marine ecosystems: ecological and geochemical significance. Limnology and Oceanography 33:702-724.

Seitzinger, S. P., J. A. Harrison, J. K. Bohlke, A. F. Bouwman, R. Lowrance, B. J. Peterson, C. Tobias, and G. Van Drecht. 2006. Denitrification across landscapes and waterscapes: a synthesis. Ecological Applications 16:2064-2090.

Seitzinger, S. P., and C. Kroeze. 1998. Global distribution of nitrous oxide production and $\mathrm{N}$ inputs in freshwater and coastal marine ecosystems. Global Biogeochemical Cycles 12: 93-113.

Seitzinger, S. P., C. Kroeze, and R. V. Styles. 2000. Global distribution of $\mathrm{N}_{2} \mathrm{O}$ emissions from aquatic systems: natural emissions and anthropogenic effects. Chemosphere: Global Change Science 2:267-279.

Stream Solute Workshop. 1990. Concepts and methods for assessing solute dynamics in stream ecosystems. Journal of the North American Benthological Society 9:95-119.

Turner, R. E., and N. N. Rabalais. 1994. Coastal eutrophication near the Mississippi River delta. Nature 368:619-621.

Valett, H. M., J. A. Morrice, C. N. Dahm, and M. E. Campana. 1996. Parent lithology, surface-groundwater exchange, and nitrate retention in headwater streams. Limnology and Oceanography 41:333-345.

Vitousek, P. M., J. D. Aber, R. W. Howarth, G. E. Likens, P. A. Matson, D. W. Shindler, W. H. Schlensinger, and D. G. Tilman. 1997. Human alteration of the global nitrogen cycle: sources and consequences. Ecological Applications 7:737750 .

Wang, W. C., Y. L. Yung, A. A. Lacis, J. Mo, and J. E. Hansen. 1976. Greenhouse effects due to man-made perturbations of trace gases. Science 194:685-690.

Webster, J. R., et al. 2003. Factors affecting ammonium uptake in streams: an inter-biome perspective. Freshwater Biology 48:1329-1352.

Wollheim, W. M., B. J. Peterson, L. A. Deegan, J. E. Hobbie, B. Hooker, W. B. Bowden, K. J. Edwardson, D. B. Arscott, A. E. Hershey, and J. Finlay. 2001. Influence of stream size on ammonium and suspended particulate nitrogen processing. Limnology and Oceanography 46:1-13. 